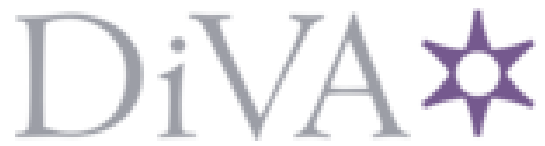

http://www.diva-portal.org

Preprint

This is the submitted version of a paper published in International Review of Retail Distribution \& Consumer Research.

Citation for the original published paper (version of record):

Håkansson, J., Li, Y., Mihaescu, O., Rudholm, N. (2019)

Big-box retail entry in urban and rural areas: Are there productivity spillovers to incumbent retailers?

International Review of Retail Distribution \& Consumer Research https://doi.org/10.1080/09593969.2018.1562956

Access to the published version may require subscription.

N.B. When citing this work, cite the original published paper.

Permanent link to this version:

http://urn.kb.se/resolve?urn=urn:nbn:se:du-27887 


\title{
Big-box retail entry in urban and rural areas: Are there productivity spillovers to incumbent retailers?
}

\author{
Johan Håkansson", Yujiao Li ${ }^{*}$, Oana Mihaescu ${ }^{+}$, Niklas Rudholm ${ }^{+}$ \\ *Dalarna University, SE- 79188 Falun, Sweden. \\ +HUI Research, SE-103 29 Stockholm, Sweden.
}

\begin{abstract}
This paper empirically measures the potential spillover effects of big-box retail entry on the productivity of incumbent retailers in the entry regions, and investigates whether the effects differ depending on the size of the new establishment relative to the size of the local market. The results indicate that big-box entry increases the productivity of incumbent firms in two of three rural entry regions where the IKEA is large relative to the local retail market, while no productivity spillover effects could be found in the case of the urban IKEA entry in Gothenburg.
\end{abstract}

Keywords: Big-box entry, Production functions, Retail productivity, Retail entry subsidies JEL classifications: D22, L11, L25, L26, P25. 


\section{INTRODUCTION}

Previous studies of the effects of big-box retail entry on surrounding businesses have mainly considered the impact on retail revenues or retail employment and have been based mainly on the entry of Wal-Mart stores in the USA, ${ }^{1}$ although there are some exceptions. For example, Jones and Doucet (2000) and Hernandez (2003) studied the Canadian market and big-box entry in general, while Daunfeldt et al. $(2016 ; 2017)$ investigated the impact of IKEA entry on revenues and employment in Swedish municipalities.

The results of these studies are ambiguous, with some finding positive (Davidson and Rummel 2000; Artz and Stone 2012; Daunfeldt et al. 2016; 2017) and others negative (e.g., Merriman et al. 2012) impacts of big-box entry on retail revenues. The findings regarding the impact on employment are also inconclusive. Basker (2005) and Hicks (2007) both found that Wal-Mart entry increased retail employment by approximately 100 jobs in the entry regions in the year of entry, while Daunfeldt et al. (2017) reported an increase in durable goods retail employment by an average of $17 \%$ in Swedish municipalities where IKEA chose to enter during the 2004-2007 period. However, others have found that big-box entry negatively affects retail employment (Jones and Doucet 2000; Hicks 2008; Neumark et al. 2008).

Moreover, the literature on the possible effects of big-box entry on the productivity of incumbent retailers in the entry regions is scarce. Basker (2007) reported that much of the productivity growth in the US general merchandise sector was driven by the growth of WalMart, while Maican and Orth (2012a) found that big-box entry in the Swedish retail food sector increased the productivity of incumbent firms in the entry regions. In a related paper, Maican and Orth (2012b) also demonstrated that more liberal entry regulations increased productivity

\footnotetext{
${ }^{1}$ See, for example, Ozment and Martin (1990); Stone (1997); Ailawadi et al. (2010); Davidson and Rummel (2000); Basker (2005); Artz and Stone (2006); Hicks (2007); Hicks (2008); Jia (2008); Neumark, Zhang, and Cicarella (2008); Sobel and Dean (2008); Paruchuri, Baum, and Potere (2009); Haltiwanger, Jarmin, and Krizan (2010); Zhu, Sing, and Dukes (2011); Artz and Stone (2012); and Merriman et al. (2012).
} 
in the Swedish retail sector, the effect being larger in small markets in Sweden. Finally, Han et al. (2018) studies how IKEA entry affect productivity using the same four Swedish IKEAentries as we do. Their study is, however, focused only on the effects in the direct vicinity to the new IKEA, testing the effects on retailers selling either complementary or substitute goods to IKEA within a 1.3 to $4.3 \mathrm{~km}$ radius around the new IKEA stores. Their results show that there are increases in productivity for incumbents selling complementary goods in two out of four entry municipalities, Haparanda and Kalmar.

Local governments often subsidize big-box entry, and one justification for such subsidies has repeatedly been that big-box retailer entry will have significant positive spillover effects on existing businesses in the region (Nilsson 2015). As noted by Greenstone et al. (2010), if such positive externalities on productivity are absent, the use of taxpayer money for such subsidies cannot be justified on economic efficiency grounds.

In Sweden, the municipalities are responsible for giving building permits through the Plan and Building Act (2010:900), and the municipalities are also the authority that in some cases subsidizes entry of big-box retailers, in most cases by the municipality bearing some of the costs related to entry. Borlänge municipality, for example, spent 350 million SEK to attract the IKEA store that opened there in 2013 (Daunfeldt et al., 2017).

Whether or not big-box retailers have spillover effects to incumbent retailers, not only very near the new stores or for certain types of products as investigated by Han et al. (2018), but more generally for all types of retail products and on the same geographic level that determines if entry will be allowed and possibly even subsidized is therefore of interest both for academia and for local policy makers. 
The purpose of this study is thus to investigate whether there are spillover effects on productivity of incumbent retailers when a big-box retailer enters a Swedish municipality or, in the case of the urban entry of Gothenburg, the metropolitan area. ${ }^{2}$

We will measure how the output of incumbent retail firms in the entry region is affected by big-box entry, while holding the levels of inputs (i.e., labour and capital) constant. ${ }^{3}$ We treat the four IKEA entries in Sweden from 2004 to 2007 as exogenous events for the incumbent retailers in the entry regions, and investigate the impact IKEA entry has on the productivity of incumbent retailers in the entry regions. We also analyse the impact of IKEA entry in both densely populated urban markets and relatively sparsely populated rural markets to investigate whether the spillover effects differ depending on the size of the new IKEA establishment relative to that of the local retail market.

We find that IKEA entry positively affects the productivity of incumbent retailers only when entry occurs in small or medium-sized Swedish regions (e.g., Haparanda and Kalmar municipalities) where the new IKEA is large relative to the existing retail market. IKEA entry increased the total factor productivity of incumbent retailers by $38 \%$ in Haparanda and $10 \%$ in Kalmar.

The article is organized as follows: Section 2 presents the theoretical foundations for why big-box entry should affect incumbent retailer productivity and Section 3 presents our identification strategy and empirical model. Section 4 discusses the data and presents some descriptive statistics, while Section 5 presents the results. Finally, Section 6 summarizes the findings of the study.

\footnotetext{
${ }^{2}$ Municipalities in the Swedish metropolitan areas are geographically very small and do not represent the market of the new big-box retailer. Also, the municipalities in the metropolitan areas need to take their neighbours into account more when using the Plan and Building Act to allow or prevent entry than does rural municipalities, and as such we have opted to use the metropolitan area rather than the individual municipality when studying the IKEA entry in Gothenburg.

${ }^{3}$ Throughout the paper, 'productivity increase' refer to an increase in retail output while holding inputs constant. The measurement of output and input variables will be described in detail in section 4 .
} 


\section{AGGLOMERATION ECONOMIES IN RETAILING}

The spatial configuration of economic activities is the outcome of two opposing types of forces, agglomeration (centripetal) forces and dispersion (centrifugal) forces, which pull and push consumers and firms into and from regions (Fujita and Thisse 2002). The external economies of scale that generate agglomeration economies are determined by supply- and demand-side linkages (O’Sullivan 2003; Baldwin and Okubo 2005). Supply-side clustering is explained by Marshall's (1920) theory of agglomeration economies, according to which firms co-locate to reduce input costs, facilitate labour matching by creating a local skilled labour pool, and benefit from knowledge spillovers (McCann 2001; O’Sullivan 2003). These economies of scale are referred to as 'external' to indicate their functional mechanism: the production costs of one firm decrease as the output of another firm, or the total output in the local market, increases (O’Sullivan 2003).

For the retailing industry, demand-side linkages or shopping externalities are equally important in explaining agglomeration economies. Shopping externalities occur when the output of one retailer is affected by the location and output of other retailers. Shopping externalities arise as the products sold are either imperfect substitutes for, or complements to, one another. The co-location of retailers selling imperfect substitutes establishes the basis of comparison shopping, while the co-location of retailers selling complements establishes the basis of one-stop shopping. Co-location helps firms increase output by taking advantage of, among other things, the marketing and reputations of their rivals (Chung and Kalnins 2001), and it also helps minimize shopping costs and uncertainty (Brown 1989).

Entry by big-box retailers may also create significant competitive pressure in the entry regions, because these large retail establishments are highly productive due to economies of scale and to innovations in logistics, distribution, inventory control, computerization and use of specialized software, and communications (Foster et al. 2006; Basker 2007). Entry by these 
highly productive big-box retailers is enough, by itself, to increase average productivity in the retail sector in the entry regions. As shown by Basker (2007), Wal-Mart's real value added per worker is $40 \%$ higher than that of other general merchandise retailers, and its productivity increased by 55\% over the 20-year 1982-2002 period.

Apart from contributing to a significant increase in productivity in the generalmerchandise sector, Wal-Mart also reduces local competitors' market shares and profit margins, causing $50-70 \%$ of the net exit of small discount retailers from the American market between 1988 and 1997 (Jia 2008). The exiting establishments were approximately 25\% less productive than the surviving incumbents, not affiliated with any national chains, and they were also smaller and younger than the surviving firms. For the Swedish retail food market, Maican and Orth (2012a) demonstrated that entry by big-box food retailers forces low-productivity stores to exit, and that surviving stores experience subsequent productivity increases of approximately 3\%, while Han et al. (2018) found that incumbent retailers selling complementary goods and located close to IKEA-entry sites increased their productivity by $35 \%$ in Haparanda and $18 \%$ in Kalmar.

Agglomeration theory and empirical results imply that the entry of big-box retailers will have the following effects on incumbent retail firm productivity. First, through the supply- and demand-side externalities discussed above, big-box entry should increase output for a given level of input factors for incumbent retailers, increasing their productivity. Second, due to the increased competition caused by big-box entry, incumbent retailers will be forced to become more productive or risk having to exit the market. Third, low-productive retailers leaving the market will be replaced by more productive retail firms, increasing competition and forcing incumbent retailers in the entry municipalities to increase their productivity.

In this paper, we will focus on identifying the effect of big-box entry on the productivity of incumbent retail firms active both before and after big-box entry. We will compare the 
productivity of retail firms in the entry regions after big-box entry with the productivity of the same firms before big-box entry, as well as with that of retail firms in the control regions throughout the study period. The results presented here should therefore be interpreted as general equilibrium, reduced-form effects that combine the impact on incumbent retail firm productivity of the big-box store entry itself and of all other direct and indirect changes in the local retail environment due to the big-box entry.

\section{IDENTIFICATION STRATEGY AND EMPIRICAL MODEL}

The fundamental identification problem that we need to solve is that a retail firm located in a region that receives a big-box retail establishment cannot also be observed in the counterfactual state of not receiving that establishment, and that big-box retailers do not enter regions randomly but rather after a deliberate process to find the most profitable entry sites.

To solve the problem, we use an identification strategy similar to that used by Greenstone et al. (2010), who compared incumbent manufacturing firms in counties that had a large manufacturing plant opening with manufacturing firms in the 'runner-up' counties that narrowly lost the plant opening. As Greenstone et al. (2010), we believe that firms choose locations to maximize profits, so that the chosen entry regions will differ substantially from random regions in Sweden. If we are to correctly measure how big-box entry affects incumbent retailers in the entry regions, we need to identify control regions that are identical to the entry regions in terms of the determinants of incumbent retailers' productivity in the absence of entry.

As many determinants of IKEA entry are unobservable to the researcher, and IKEA itself does not reveal its entry strategy, we choose the next round of IKEA entries, completed during the 2013-2016 period, as control municipalities for three of the four IKEA entries in Sweden during the 2004-2007 period, i.e., Kalmar (2006), Haparanda (2006), and Karlstad (2007). 
The municipalities in the 2013-2016 round of entries, i.e., Borlänge, Uddevalla, and Umeå, are similar to the entry municipalities in several of the observables. For example, both Karlstad and Umeå have local universities, and both Borlänge and Kalmar have university college campuses, while the municipalities of Haparanda and Uddevalla have no higher education institutions. In addition, although the mentioned municipalities are smaller cities (fewer than 80,000 inhabitants), the markets in the entry and control groups are essentially rural and similar in population density (fewer than 80 inhabitants per sq $\mathrm{km}$ ) and retail industry size. Most importantly, however, is that both the entry- and control-group municipalities were deemed suitable entry locations by IKEA itself within a 10-year period, indicating that these municipalities should be similar in terms of both observable and unobservable determinants of IKEA entry. Previous studies (Daunfeldt et al., 2016, 2017) have also demonstrated that the regional spillover effects of an IKEA entry are spatially limited to the entry municipalities, so we focus our study on the potential spillover effects within the above-mentioned municipalities.

The fourth IKEA entry under study took place in the urban area of Gothenburg, and is the second IKEA store in the region. Gothenburg is Sweden's second largest city; its metropolitan area consists of 13 municipalities and has approximately 1 million inhabitants. Gothenburg is the urban center of western Sweden and is surrounded by a rather sparsely settled surrounding area of smaller cities. The metropolitan area is divided into a northwestern and a southeastern part by the river Göta älv, which shapes daily travel behaviour in the city. An IKEA store has been operating on the southern edge of the metropolitan core since 1972. The outlet investigated here was established in 2004, north of the river, on the northern edge of the metropolitan core.

When comparing big-box entry in metropolitan areas, only two other Swedish cities can be considered potential controls for Gothenburg: Stockholm and Malmö. However, Malmö is a special case with its close ties to another metropolitan area, Copenhagen. Malmö city also has 
other geographical characteristics making it less suited as a control for Gothenburg. For example, although Malmö can be considered the regional center of southern Sweden, its position relative to the surrounding cities is much weaker than that of Gothenburg due to a much denser structure of competing, fairly large cities in the surrounding area.

The Stockholm metropolitan area consists of 26 municipalities, with somewhat more than 2 million inhabitants. Unlike Malmö, the Stockholm metropolitan area has several properties that make it a suitable control for Gothenburg. First, like Gothenburg, it is monocentric with the municipality of Stockholm at its core, with surrounding municipalities mostly consisting of various forms of suburban areas and some smaller towns located on the fringes of the metropolitan area. Second, Stockholm's metropolitan area is, as in Gothenburg, divided by water into a southern and a northern part, which also shapes daily mobility and travel patterns. Third, two IKEA stores, one in the northern and another in the southern part of the metropolitan core, are operating in Stockholm, meaning that both Stockholm and Gothenburg have been deemed suitable as two-store metropolitan areas by IKEA.

This first step of our analysis minimizes regional heterogeneity, and provides us with the means for comparing retail firms located in IKEA-entry regions both with themselves in the period before entry, and with retail firms located in non-entry regions that have also been deemed suitable for IKEA entry at a different time.

In the second step of the analysis, we use a production-function regression model to measure the effect of a new IKEA store on the productivity of incumbent retail firms located in the entry municipalities. In this model, we assume that the retailers are using production technology that can be captured by the transcendental logarithmic (translog) production function developed by Christensen et al. (1971). This functional form can be seen as a secondorder Taylor series approximation (with a remainder term) of an arbitrary production function, and can be written as follows: 
$\ln Q_{i, t}=\beta_{1} \ln L_{i, t-1}+\beta_{2} \ln K_{i, t-1}+\beta_{3} \ln L_{i, t-1}^{2}+\beta_{4} \ln K_{i, t-1}^{2}+\beta_{5} \ln L_{i, t-1} \ln K_{i, t-1}+R_{i, t},(1)$

where $Q_{i . t}$ is a measure of output in retailing and $L_{i, t-1}$ and $K_{i, t-1}$ are measures of the labour and capital inputs in retailing, respectively, both lagged one period to alleviate a potential endogeneity problem. Finally, $R_{i t}$ is the remainder term of the Taylor series approximation, which in most empirical work is assumed to contain a constant and a random error term, making Equation (1) a standard ordinary least squares regression model to be estimated. However, as we are interested in measuring how the entry of an IKEA store in a region affects the productivity of incumbent firms, i.e., whether IKEA entry causes a shift in the production function of the affected firms, holding the levels of the capital and labour inputs constant, our remainder term needs to take this into account. As such, we propose the following remainder term:

$$
R_{i, t}=\beta_{0}+\beta_{6} T R_{i}+\beta_{7} T P_{t}+\beta_{8}\left(T P_{t} * T R_{i}\right)+\varepsilon_{i, t},(2)
$$

where $\beta_{0}$ is a constant, $T P_{t}$ is an indicator variable equal to one for the treatment period (i.e., after IKEA entry into the investigated region), and zero otherwise, and $T R_{i}$ is an indicator variable equal to one for firms located in the IKEA-entry region under investigation throughout the study period, and zero otherwise. Our key variable of interest is the interaction between $T P_{t}$ and $T R_{i}$, as this will provide an estimate of the treatment effect, i.e., of how the output of incumbent retailers in the entry region after IKEA entry compares with their own output before entry, and with the output of control group retailers throughout the study period, holding the levels of inputs (i.e., labour and capital) constant. This type of difference-in-difference estimator is one of the tools most frequently used in applied economics research to evaluate the effects of public interventions and other treatments of interest on relevant outcome variables (Abadie 2005). 
We expect $\beta_{8} \geq 0$, i.e., that firms in the IKEA-entry regions either became more productive in that they increased their output for given levels of labour and capital in the period after IKEA entry or, alternatively, were not affected at all. If agglomeration economies caused by the new IKEA create, for example, knowledge spillovers that make labour more productive, or if there are spillovers from the marketing and reputations of other firms in the entry region, we would expect a positive outcome. However, co-location with IKEA also intensifies competition between firms in the region, and could do so to the extent that the positive agglomeration effects are completely counteracted. We do not expect to observe negative outcomes of this process, because low-productive retailers would then choose to relocate to new markets, restoring average productivity in the entry regions to their pre-IKEA levels.

All variables used will be described in detail in the next section, along with descriptive statistics, and we will test our hypothesis that $\beta_{8} \geq 0$ by estimating: ${ }^{4}$

$$
\begin{aligned}
& \ln Q_{i, t}=\beta_{0}+\beta_{1} \ln L_{i, t-1}+\beta_{2} \ln K_{i, t-1}+\beta_{3} \ln L_{i, t-1}^{2}+\beta_{4} \ln K_{i, t-1}^{2} \\
& +\beta_{5} \ln L_{i, t-1} \ln K_{i, t-1}+\beta_{6} T R_{i}+\beta_{7} T P_{t}+\beta_{8}\left(T P_{t} * T R_{i}\right)+\varepsilon_{i, t} .
\end{aligned}
$$

\section{DATA AND DESCRIPTIVE STATISTICS}

IKEA today has 20 stores in Sweden. After Älmhult (1958) and Huddinge (in Stockholm) in 1965 came stores in Sundsvall and Malmö in 1966, then Mölndal (outside Gothenburg) in 1972, Linköping in 1977, Jönköping and Gävle in 1981, Helsingborg, Örebro, and Uppsala in 1982, Västerås in 1984, Järfälla (outside Stockholm) in 1993, Gothenburg in 2004, Kalmar and Haparanda in 2006, Karlstad in 2007, and Borlänge and Uddevalla in 2013. Finally, a store was opened in Umeå in February 2016. In Figure 1, the entries studied here (i.e., Gothenburg

\footnotetext{
${ }^{4}$ To obtain the change in factor productivity due to IKEA entry in percentage terms, the formula $100 \times\left[\mathrm{e}\left(\beta_{8}\right)-\right.$ 1] is used to calculate the effects presented in Table 2.
} 
metropolitan area and Haparanda, Kalmar, and Karlstad municipalities) are marked in red stripes while the control regions (i.e., Stockholm metropolitan area and Borlänge, Uddevalla, and Umeå municipalities) are marked in yellow. The other previous IKEA-entry municipalities are marked in green.

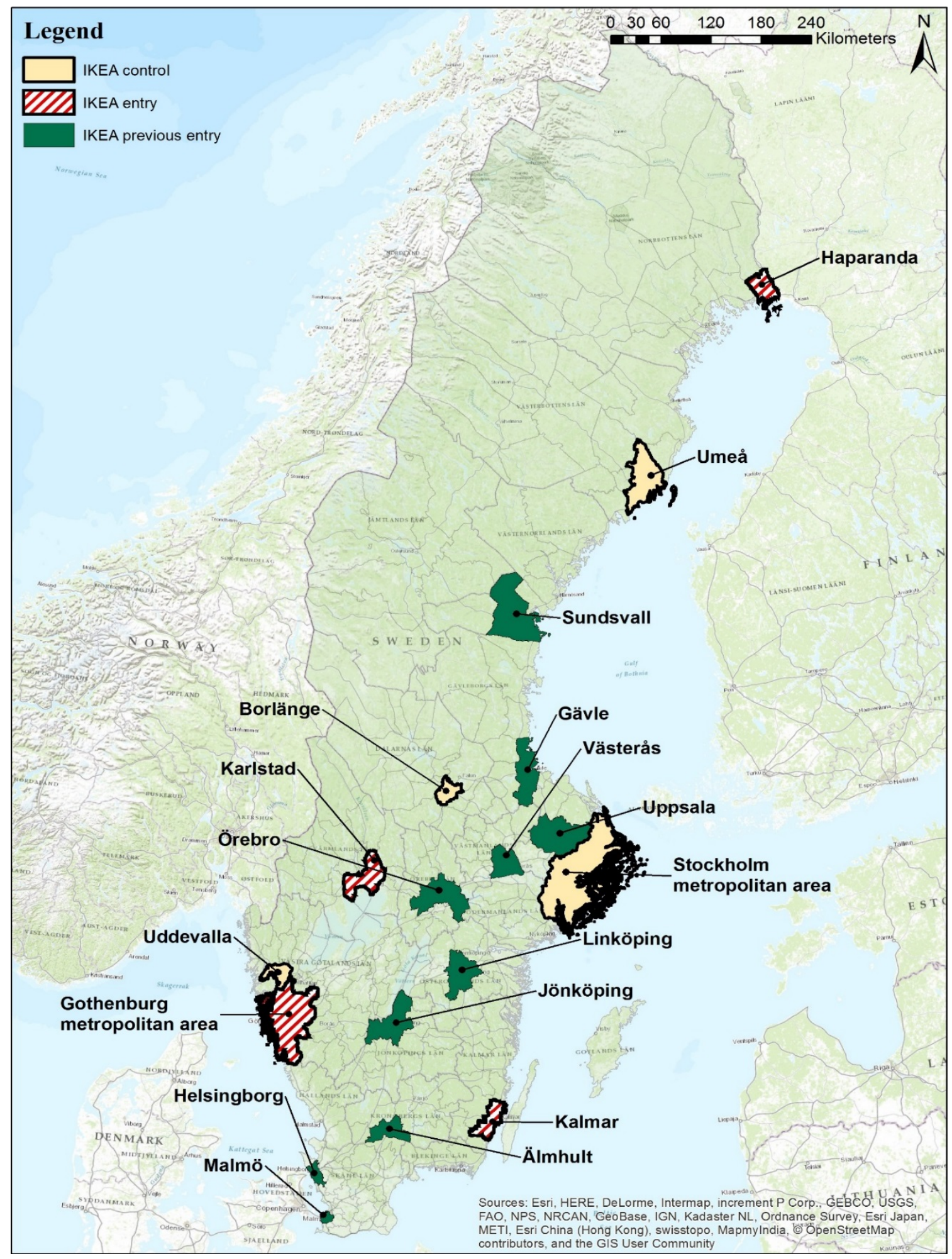


Fig. 1 IKEA-entry, control, and previous IKEA-entry municipalities in Sweden

All limited liability firms in Sweden are required to submit annual reports to the Swedish Patent and Registration Office (PRV). To investigate the effect of new IKEA stores on the productivity of incumbent retailers in the entry regions, we use annual report data from Swedish retail firms located in either IKEA-entry (i.e., Gothenburg, Haparanda, Kalmar, and Karlstad) or control (i.e., Stockholm, Borlänge, Uddevalla, and Umeå) regions.

Our urban data cover retail firms located in the Gothenburg metropolitan area (entry) and the Stockholm metropolitan area (control) and consist of 11486 firm-year observations, while the data covering rural municipalities (i.e., the entry municipalities Haparanda, Karlstad, and Kalmar and the control municipalities Uddevalla, Borlänge, and Umeå) consist of 8296 firm-year observations, 2286 of which relate to Haparanda and the three controls, 3110 to Karlstad and controls, and 2900 to Kalmar and controls. The data were collected by PAR, a Swedish consulting firm that gathers this information from PRV, and include all variables registered in the annual reports.

Griffith and Harmgardt (2005) and Reynolds et al. (2005) have pointed out some issues concerning how to measure output in retailing. When analyzing productivity in retailing, increased productivity is usually measured as the increase in revenues or value added per worker (Reynolds et al. 2005), sometimes also accounting for other inputs such as capital. Revenues are quantity sold times the selling price, while value added is the value of output minus the cost of goods sold and other intermediate inputs.

First, it should be noted that using value added as the measure of output is not an option in the present setting, because it consists two-thirds of salaries, creating severe endogeneity problems if one were to estimate Equation (3) using labor as one of the independent variables. Second, to make it possible to compare the different goods sold by different types of retailers, 
controlling for price is crucial (Griffith and Harmgardt 2005). As such, the revenues of the studied retail firms must be discounted using a relevant price index, so the dependent variable, retailing output $\left(Q_{i t}\right)$, is measured for each firm (index $i$ ) and year (index $t$ ) and is defined as revenues of firm $i$ in year $t$ discounted by the Swedish consumer price index (CPI).

The identifying assumption in the difference-in-difference regression model presented in Equation (3) is that incumbent retailers in the entry and control regions would have parallel trends in the outcome variable in the absence of treatment. The development of retail output in the entry regions in the absence of IKEA entry is of course impossible to observe empirically, but we can observe the pre-entry trends in the outcome variable, $\ln Q_{i t}$, in both the entry and control regions. Table 1 presents the mean value of $\ln Q_{i t}$ for firms located in the entry and control regions for the study period; these data indicate that both the levels and trends of $\ln Q_{i t}$ are similar in the entry and control regions in the pre-entry periods.

Table 1 Mean log-transformed output, $\ln Q_{i t}, 2000-2010$

\begin{tabular}{lcccc}
\hline Year & $\begin{array}{c}\text { Rural } \\
\text { entry }\end{array}$ & $\begin{array}{l}\text { Rural } \\
\text { control }\end{array}$ & $\begin{array}{c}\text { Urban } \\
\text { entry }\end{array}$ & $\begin{array}{c}\text { Urban } \\
\text { control }\end{array}$ \\
\hline 2000 & 15.64 & 15.35 & 15.13 & 15.08 \\
2001 & 15.58 & 15.26 & 15.08 & 15.11 \\
2002 & 15.45 & 15.17 & 15.07 & 15.06 \\
2003 & 15.71 & 15.23 & 15.05 & 15.04 \\
2004 & 15.65 & 15.25 & 15.09 & 15.03 \\
2005 & 15.84 & 15.32 & 15.10 & 15.07 \\
2006 & 15.53 & 15.31 & 15.16 & 15.05 \\
2007 & 15.57 & 15.37 & 15.14 & 15.06 \\
2008 & 15.72 & 15.42 & 15.14 & 15.04 \\
2009 & 16.08 & 15.36 & 15.15 & 15.08 \\
\hline
\end{tabular}




\begin{tabular}{lllll}
\hline 2010 & 15.76 & 15.38 & 15.21 & 15.10 \\
\hline
\end{tabular}

The log transformation of output in retailing $\left(Q_{i t}\right)$ has the benefit of making the parameter estimate related to the effect of IKEA entry on incumbent-firm productivity from our difference-in-difference model interpretable in percentage terms after some calculations (see footnote 4). In addition, as can be seen in Fig 2, the log-transformed output (ln $\left.Q_{i t}\right)$ is approximately normally distributed for both the entry and control regions.

Labour $\left(L_{i, t-1}\right)$ is measured as the number of employees in firm $i$ at time $t-1$, while capital $\left(K_{i, t-1}\right)$ is measured as the value of the capital stock, i.e., the value of the land, buildings, and machinery of firm $i$ at time $t-1$. Since both variables are $\log$ transformed, the parameter estimates from the estimation of Equation (3) can be interpreted as elasticities. Descriptive statistics for all variables included in the empirical model are presented in Table 2, and the means and standard deviations of output, labour, and capital indicate that the data from the entry and control municipalities are quite similar, not only for retail output but also for our measures of capital and labour. 

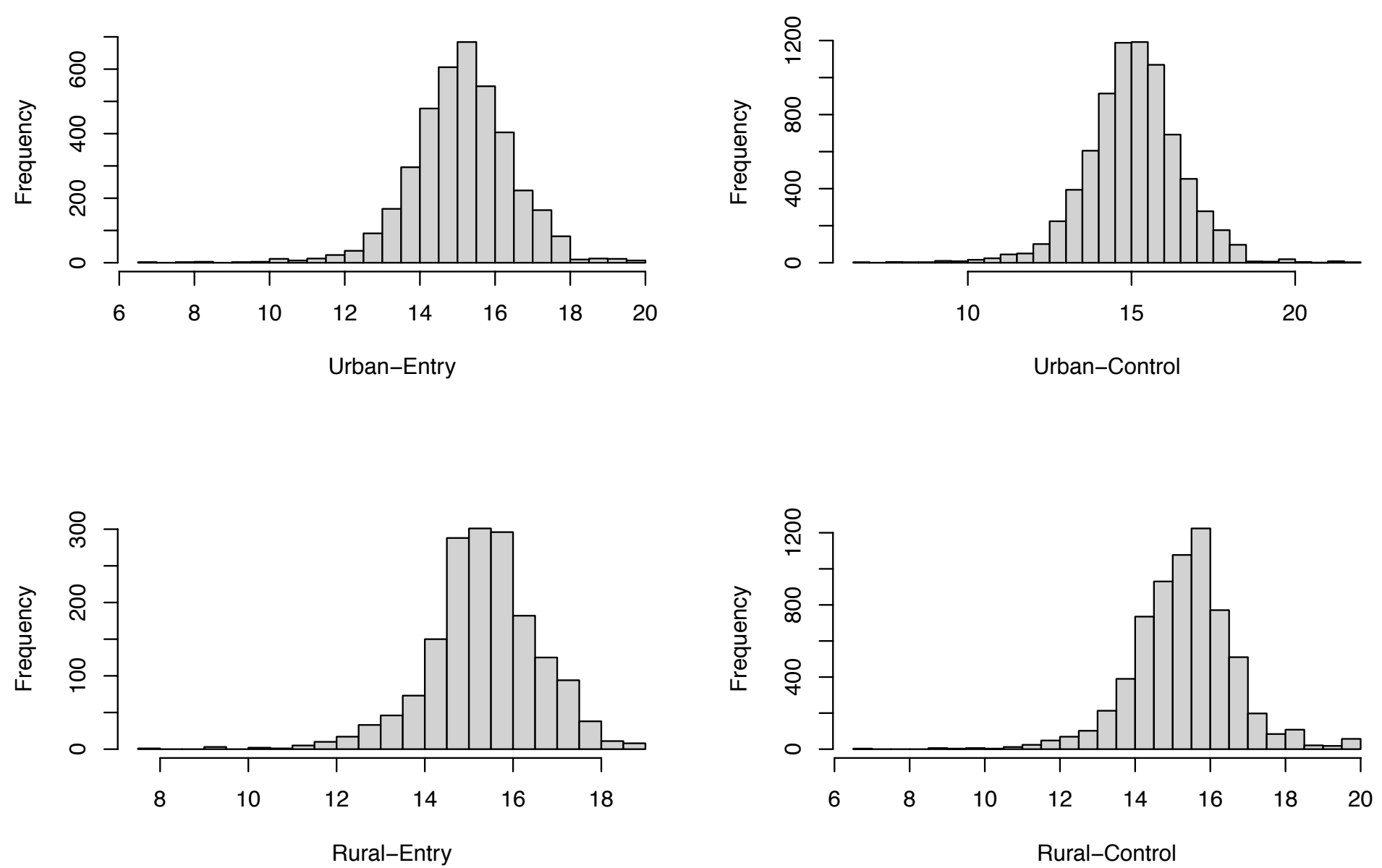

Fig 2 Histogram of log-transformed output, $\ln Q_{i t}$, entry and control municipalities 
Table 2 Dependent and independent variables: data source, means, and standard deviations

\begin{tabular}{|c|c|c|c|c|c|c|}
\hline Variable & $\begin{array}{l}\text { Urban } \\
\text { entry }\end{array}$ & $\begin{array}{l}\text { Urban } \\
\text { control }\end{array}$ & $\begin{array}{l}\text { Rural } \\
\text { entry }\end{array}$ & $\begin{array}{l}\text { Rural } \\
\text { control }\end{array}$ & Variable description & Data source \\
\hline $\ln Q_{i, t}$ & $\begin{array}{l}15.12 \\
(1.34)\end{array}$ & $\begin{array}{l}15.06 \\
(1.44)\end{array}$ & $\begin{array}{l}15.33 \\
(1.27)\end{array}$ & $\begin{array}{l}15.31 \\
(1.35)\end{array}$ & $\begin{array}{l}\text { Revenues of firm } i \text { in year } t \text { discounted } \\
\text { by CPI in SEK. }\end{array}$ & $\begin{array}{l}\text { PAR/Statistics } \\
\text { Sweden/own calculations }\end{array}$ \\
\hline $\ln K_{i, t-1}$ & $\begin{array}{l}4.30 \\
(1.65)\end{array}$ & $\begin{array}{l}4.12 \\
(1.72)\end{array}$ & $\begin{array}{l}4.67 \\
(1.84)\end{array}$ & $\begin{array}{l}4.64 \\
(1.87)\end{array}$ & $\begin{array}{l}\text { Sum of the value of the land, buildings, } \\
\text { and machinery of firm } i \text { at time } t-1 \text { in } \\
\text { thousands of SEK. }\end{array}$ & PAR/own calculations \\
\hline $\ln L_{i, t-1}$ & $\begin{array}{l}1.43 \\
(0.69)\end{array}$ & $\begin{array}{l}1.38 \\
(0.73)\end{array}$ & $\begin{array}{l}1.50 \\
(0.64)\end{array}$ & $\begin{array}{l}1.50 \\
(0.70)\end{array}$ & $\begin{array}{l}\text { Number of employees in firm } i \text { at time } t \\
-1 \text {. }\end{array}$ & PAR/own calculations \\
\hline $\ln K_{i, t-1}^{2}$ & $\begin{array}{l}21.21 \\
(14.79)\end{array}$ & $\begin{array}{l}19.89 \\
(16.44)\end{array}$ & $\begin{array}{l}25.18 \\
(18.88)\end{array}$ & $\begin{array}{l}25.01 \\
(18.98)\end{array}$ & $\ln K_{i,-1}$ squared & PAR/own calculations \\
\hline $\ln L_{i, t-1}^{2}$ & $\begin{array}{l}2.50 \\
(2.42)\end{array}$ & $\begin{array}{l}2.44 \\
(2.70)\end{array}$ & $\begin{array}{l}2.65 \\
(2.19)\end{array}$ & $\begin{array}{l}2.73 \\
(2.65)\end{array}$ & $\ln L_{i, t-1}$ squared & PAR/own calculations \\
\hline $\ln L_{i, t-1} \ln K_{i, t-1}$ & $\begin{array}{l}6.69 \\
(5.36)\end{array}$ & $\begin{array}{l}6.35 \\
(5.92)\end{array}$ & $\begin{array}{l}7.52 \\
(5.47)\end{array}$ & $\begin{array}{l}7.61 \\
(6.14)\end{array}$ & $\ln L_{i, t-1}$ multiplied by $\ln K_{i, t-1}$ & PAR/own calculations \\
\hline$T P_{i, t}$ & $\begin{array}{l}0.47 \\
(0.50)\end{array}$ & $\begin{array}{l}0.48 \\
(0.50)\end{array}$ & $\begin{array}{l}0.48 \\
(0.50)\end{array}$ & $\begin{array}{l}0.46 \\
(0.50)\end{array}$ & $\begin{array}{l}\text { Indicator variable equal to one for } \\
\text { treatment period years }\end{array}$ & Own calculations \\
\hline$T R_{i, t}$ & $\begin{array}{l}1 \\
(0)\end{array}$ & $\begin{array}{l}0 \\
(0)\end{array}$ & $\begin{array}{l}1 \\
(0)\end{array}$ & $\begin{array}{l}0 \\
(0)\end{array}$ & $\begin{array}{l}\text { Indicator variable equal to one for } \\
\text { retailers located in treatment } \\
\text { municipalities }\end{array}$ & Own calculations \\
\hline$T P_{i, t} \times T R_{i, t}$ & $\begin{array}{l}0.47 \\
(0.50)\end{array}$ & $\begin{array}{l}0 \\
(0)\end{array}$ & $\begin{array}{l}0.48 \\
(0.50)\end{array}$ & $\begin{array}{l}0 \\
(0)\end{array}$ & $\begin{array}{l}\text { Indicator variable equal to one for } \\
\text { retailers located in treatment } \\
\text { municipalities in treatment years }\end{array}$ & Own calculations \\
\hline
\end{tabular}




\section{ESTIMATION RESULTS}

The results regarding the main variable of interest, i.e., the interaction term for the effect of IKEA entry on the productivity of incumbent retailers, recalculated in percentage terms, are presented in Table 3. The first row of results is from the estimation of Equation (3), i.e., the most general specification. To show the robustness of our results to changes in specification, Table 3 also includes the results of estimations of a Cobb-Douglas specification and of a nonproduction-function, standard difference-in-difference specification. It should be noted, however, that the model preferred on statistical grounds is the most general, translogspecification model, so we will focus our discussion on the results based on this specification. As a final control of the robustness of the estimates, Table 3 also includes the results of additional estimations of Equation (3), but where retail firms from the set of control municipalities from Daunfeldt et al. $(2016 ; 2017)$ have been used in the estimations instead.

Table 3 Estimation results of $T P_{i, t} \times T R_{i, t}$, dependent variable $\ln Q_{i, t} ;$ results in percentage terms

\begin{tabular}{lllll}
\hline & Gothenburg & Haparanda & Karlstad & Kalmar \\
\hline Translog model & 3.87 & $38.26^{*}$ & 4.92 & $10.08^{*}$ \\
Cobb-Douglas model & 4.19 & $41.06^{*}$ & 5.02 & 10.63 \\
$\begin{array}{l}\text { Difference-in-difference model } \\
\begin{array}{l}\text { Daunfeldt et al. (2017) control } \\
\text { municipalities }\end{array}\end{array}$ & 0.00 & $75.24^{*}$ & -0.90 & 4.71 \\
$\begin{array}{l}\text { Daunfeldt et al. (2016) control } \\
\text { municipalities }\end{array}$ & N.A. & 21.05 & -0.60 & 5.97 \\
** significant at the 5\% level, * significant at the 10\% level & 13.31 & 1.41 & $17.23^{* *}$ \\
\end{tabular}

As can be seen in Table 3, the effects of IKEA entry on the productivity of incumbent retailers in Haparanda and Kalmar are statistically significant. For Haparanda, this result is robust to changes in the production-function specification, but not to choose of control municipalities. For Kalmar, a positive effect of IKEA entry on productivity is found for the preferred translog model. However, the result turns insignificant in the Cobb-Douglas and standard difference-in-difference estimations and when using the controls from Daunfeldt et al. 
(2017). When using the control municipalities from Daunfeldt et al. (2016), there is an increase in productivity of $17 \%$ due to IKEA entry. Still, in the preferred specification, IKEA entry has a statistically significant positive effect on the productivity of incumbent retailers in Kalmar. For the two remaining entry municipalities, Gothenburg and Karlstad, there are no statistically significant results irrespective of model specification or choice of control municipalities.

As for the size of the effects, the increase in productivity due to IKEA entry is $38 \%$ in Haparanda but only $10 \%$ in Kalmar. The results for Kalmar are in line with the results reported by Greenstone et al. (2010), who found that entry by large manufacturing plants in the USA increased the productivity of incumbent manufacturing firms by $12 \%$. The large effect observed in Haparanda is to be expected because the pre-IKEA retail sector in Haparanda was less developed than in other Swedish municipalities of a similar size (i.e., 9800 inhabitants), while in the post-IKEA period, Haparanda retailing has attracted consumers not only from Haparanda itself but also from much of northern Sweden and northern Finland. HUI Research, a Swedish consultancy firm which focuses on the retail sector, calculates a sales index that relates a municipality's total retail sales to its population. The index is constructed so that a municipality with an index value of 100 can be interpreted as having a retail sector selling as much as could be expected given the population of the municipality. In 2005, the year before IKEA entry, the index for Haparanda was 90; in 2010, five years after IKEA entry, the index value had increased to 267 , equalling a $300 \%$ increase. Another way of indicating the large effect IKEA entry had on retailing in Haparanda is to compare total municipality level turnover in durable goods retailing before and after IKEA entry. The year before IKEA entry, total turnover was approximately 140 million SEK, while 5 years after it had grown to 1078 million SEK. These 
numbers include the turnover by IKEA itself, but they are still indicative of the impact that IKEA had on retailing in Haparanda. ${ }^{5}$

To sum up, the results indicate large, statistically significant productivity increases for incumbents in the smallest rural IKEA-entry municipality (Haparanda, 9800 inhabitants), and smaller, but still statistically significant, productivity increases in the larger entry municipality of Kalmar (65 000 inhabitants). No statistically significant effects can be found in the largest rural entry municipality (Karlstad, 87000 inhabitants) or in the case of urban entry in Gothenburg (550 000 inhabitants).

\section{SUMMARY AND DISCUSSION}

A new IKEA store is often considered particularly important for regional development because it tends to attract consumers from far away, and the claim that IKEA benefits a region was supported by Daunfeldt et al. (2017), who found that a new IKEA store increased both durable-goods revenues and the number of employees in the entry regions. The view that IKEA is of particular importance for regional development is further supported by Swedish municipalities spending considerable amounts of money for attracting IKEA. Borlänge municipality, for example, spent 350 million SEK to attract the IKEA store that opened up in 2013 (Daunfeldt et al., 2017). Whether or not big-box entry is beneficial to a region is thus of interest, not only in terms of policy implications and resources spent to attract IKEA or other big-box retailers, but also since there is an ongoing debate on how external shopping centers affect local communities and existing retailers in the entry areas.

\footnotetext{
${ }^{5}$ Data regarding the sales index and total durable goods retail turnover for Haparanda was collected from Trade in Sweden (Handeln i Sverige), which is a free database that includes information on a variety of retail related variables, e.g., turnover, employment, the sales index, and their development over time. The database is maintained by HUI Research and can be accessed at http://www.handelnisverige.se/ (in Swedish).
} 
Most previous studies have focused on the impact of big-box entry on sales and/or employment in incumbent retailers in the entry areas. The development of sales and employment are both important determinants of the economic wellbeing of the retail sector in a region, but an equally important factor, overlooked by most previous studies, is the development of productivity in incumbent retailers after big-box entry into a region. As such, this paper sought to empirically measure the potential spillover effects of big-box retail entry on the productivity of incumbent retailers in the entry municipalities, and to investigate whether the impact of big-box entry on productivity differs depending on the size of the new establishment relative to the total size of the local market.

There are several reasons to expect big-box entry to have a positive impact on the productivity of incumbent retailers. First, according to Marshall (1920), firms co-locate to reduce input costs, facilitate labour matching by creating a local skilled labour pool, and benefit from knowledge spillovers (McCann 2001; O’Sullivan 2003). Second, shopping externalities arising from the sales of either complements or imperfect substitutes can also create agglomeration economies in retailing. The co-location of retailers selling imperfect substitutes establishes the basis of comparison shopping, while the co-location of retailers selling complements establishes the basis of one-stop shopping, both of which potentially have positive spillover effects on local retailers. Third, entry by a big-box retailer will increase competition both directly and indirectly, forcing less productive retailers out of the market and creating room for more productive firms. Incumbents that want to stay in the market must increase their productivity to keep up with the big-box and/or the new retail entrants.

Although the existence of positive spillover effects seems reasonable from a theoretical perspective, it is difficult to empirically estimate productivity spillover effects because new bigbox locations are chosen to maximize profits, so the retail sectors in entry municipalities are likely to differ significantly from those in randomly selected Swedish regions. To address this 
empirical problem, we chose control regions in two ways. For the IKEA entries in Haparanda, Kalmar, and Karlstad, we use the three municipalities that IKEA itself selected for entry in the next round of IKEA startups in Sweden (i.e., Borlänge, Uddevalla, and Umeå) as controls. For the IKEA entry in Gothenburg in 2004, the Stockholm metropolitan area is used as the comparison region. Then, in a second step, the development of productivity is compared between retailers located in the IKEA-entry regions and in the control regions using a translog production-function model with a difference-in-difference remainder term.

The results indicate that IKEA entry has positive spillover effects on incumbent retailers' productivity in small and medium-sized Swedish municipalities such as Haparanda and Kalmar, while no productivity increases could be found in the larger entry locations of Karlstad and Gothenburg. It seems that to have a positive impact on the productivity of incumbent retailers, the size of the big-box entry relative to the existing retail market must be substantial.

As mentioned, Swedish municipalities often subsidize big-box entry with the justification that big-box retailer entry will have significant positive spillover effects on incumbent retailers in the region (Nilsson 2015). As noted by Greenstone et al. (2010), if such positive externalities on productivity are absent, the use of taxpayer money for such subsidies cannot be justified on economic efficiency grounds. However, if positive spillovers are present, the socially optimal location is the one that maximizes the sum of firm profits for the entrant plus the positive spillovers. In this case, a subsidy that internalizes this externality will increase welfare. Our results suggest that big-box entries in small and medium-sized Swedish municipalities warrant subsidies equal to the positive spillovers in productivity that they create, while big-box entry in large municipalities, where no positive spillovers are found, do not.

However, as municipal income in Sweden is mainly financed through local taxes on employment, and the subsidies thereby financed by all local taxpayers, there are two additional 
issues to consider. Firstly, since incumbent retailers in the municipality do not pay taxes at the local but rather at the national level, using this type of subsidy will imply a certain redistribution of resources from local taxpayers to local retailers. Not only that, by comparing our results in this paper to the ones presented in Han et al. (2018), we find that most of the productivity effects of the new IKEA stores are for incumbent retailers both located near the new IKEA and selling substitute goods to IKEA, making the group of retail firms that gain from IKEA entry even smaller. Finally, from a purely fiscal perspective of the municipalities, it might be difficult to re-coup their investment since retailer profits are not taxed locally in Sweden and the cost of the subsidies are often quite substantial.

\section{REFERENCES}

Abadie A (2005) Semiparametric difference-in-difference estimator. Rev Econ Stud 72(1):119. doi:10.1111/0034-6527.00321

Ailawadi KL, Zhang J, Krishna A, Kruger M (2010) When Wal-Mart enters: how incumbent retailers react and how this affects their sales outcomes. J Market Res 47:577-593. doi: 10.1509/jmkr.47.4.577

Artz GM, Stone K (2006) Analyzing the impact of Wal-Mart supercenters on local food store sales. Am J Agric Econ 88:1296-1303. doi: 10.1111/j.1467-8276.2006.00948.x

Artz GM, Stone K (2012) Revisiting Wal-Mart's impact on Iowa small-town retail: 25 years later. Econ Dev Q 26:298-310. doi: 10.1177/0891242412461828

Baldwin R, Okubo T (2005) Heterogeneous firms, agglomeration and economic geography: spatial selection and sorting. J Econ Geogr 6:323-346. doi: https://doi.org/10.1093/jeg/lbi020

Basker E (2007) The causes and consequences of Wal-Mart's growth. J Econ Perspect 21:177-198. doi: 10.1257/jep.21.3.177

Basker E (2005) Job creation or destruction? Labour market effects of Wal-Mart expansion. Rev Econ Stat 87:174-183. doi: 10.1162/0034653053327568

Brown S (1989) Retail location theory: the legacy of Harold Hotelling. J Retailing 65:450-470

Christensen LR, Jorgenson DW, Lau LJ (1971) Conjugate duality and the transcendental logarithmic production function. Econometrica 39:255-256 
Chung W, Kalnins A (2001) Agglomeration effects and performance: a test of the Texas lodging industry. Strat Manage J 22:969-988. doi: 10.1002/smj.178

Daunfeldt S-O, Mihaescu O, Nilsson H, Rudholm R (2017) What happens when IKEA comes to town? Reg Stud 51(2):313-323. doi: 10.1080/00343404.2015.1100287

Daunfeldt S-O, Mihaescu O, Nilsson H, Rudholm R (2016) When IKEA Enters: Do Local Retailers Win or Lose? Working Paper No. 109, HUI Research, Stockholm

Davidson SM, Rummel A (2000) Retail changes associated with Wal-Mart's entry into Maine. Int J Retail Distrib Manag 28:162-169. doi: 10.1108/09590550010319913

Foster L, Haltiwanger J, Krizan CJ (2001) The Link Between Aggregate and Micro Productivity Growth: Evidence from Retail Trade. Working Paper No. 13783, National Bureau of Economic Research, Cambridge

Foster L, Haltiwanger J, Krizan CJ (2006) Market selection, reallocation, and restructuring in the U.S. retail trade sector in the 1990s. Rev Econ Stat 88:748-758. doi: 10.1162/rest.88.4.748

Fujita M, Thisse J-F (2002) Economics of agglomeration: cities, industrial location, and regional growth. Cambridge University Press, Cambridge

Greenstone M, Hornbeck R, Moretti E (2010) Identifying agglomeration spillovers: evidence from winners and losers of large plant openings. J Pol Econ 118:536-598. doi: $10.1086 / 653714$

Griffith R, Harmgardt H (2005) Retail productivity. Int Rev Retail Distrib Consum Res 15:281-290. doi: 10.1080/09593960500119481

Haltiwanger J, Jarmin RR, Krizan CJ (2010) Mom-and-pop meet big-box: complements or substitutes? J Urb Econ 67:116-134. doi: 10.3386/w15348

Hernandez T (2003) The impact of big-box internationalization on a national market: a case study of Home Depot Inc. in Canada. Int Rev Retail Distrib Consum Res 13:77-98. doi: $10.1080 / 0959396032000065364$

Hicks MJ (2007) Job turnover and wages in the retail sector: the influence of Wal-Mart. J Priv Enterp 22:137-160. http://EconPapers.repec.org/RePEc:jpe:journl:889. Accessed 2 September 2015.

Hicks MJ (2008) Estimating Wal-Mart's impact in Maryland: a test of identification strategies and endogeneity tests. East Econ J 34:56-73. doi: 10.1057/palgrave.eej.9050002

Jia P (2008) What happens when Wal-Mart comes to town: an empirical analysis of the discount retailing industry. Econometrica 76:1263-1316. doi: 10.3982/ECTA6649 
Jones K, Doucet M (2000) Big-box retailing and the urban retail structure: the case of the Toronto area. J Retail Cons Serv 7:233-247. doi: 10.1016/S0969-6989(00)00021-7

Maican F, Orth M (2012a) Productivity dynamics and the role of 'big-box' entrants in retailing. Working Paper No. 898, Research Institute of Industrial Economics, Stockholm

Maican F, Orth M (2012b) A dynamic analysis of entry regulations and productivity in retail trade. Working Paper No. 939, Research Institute of Industrial Economics, Stockholm

Marshall A (1920) Principles of Economics. McMillan and Co., London

McCann P (2001) Urban and Regional Economics. Oxford University Press, Oxford

Merriman D, Persky J, Davis J, Baiman R (2012) The impact of an urban Wal-Mart store on area businesses: the Chicago case. Econ Dev Q 26:321-333. doi: $10.1177 / 0891242412457985$

Neumark D, Zhang J, Cicarella J (2008) The effect of Wal-Mart on local labour markets. J Urb Econ 63:405-430. doi: 10.3386/w11782

Nilsson H (2015) The Impact of Big-boxes on Local Retail: What Happens when IKEA Comes to Town? Licentiate thesis, Dalarna University

Olley SG, Pakes A (1996) The dynamics of productivity in the telecommunications equipment industry. Econometrica 64:1263-1297. doi: 10.2307/2171831

O’Sullivan A (2003) Urban economics. McGraw-Hill/Irwin, New York

Ozment J, Martin G (1990) Changes in the competitive environments of rural trade areas: effects of discount retail chains. J Bus Res 21:277-287. doi: 10.1016/01482963(90)90033-A

Paruchuri S, Baum JAC, Potere D (2009) The Wal-Mart effect: wave of destruction or creative destruction? Econ Geogr 85:209-236. doi: 10.1111/j.1944-8287.2009.01023.x

Reynolds J, Howard E, Dragun D, Rosewell B, Ormerod P (2005) Assessing the productivity of the UK retail sector. Int Rev Retail Distrib Cons Res 15:237-280. doi: $10.1080 / 09593960500119416$

Sobel RS, Andrea MD (2008) Has Wal-Mart buried mom-and-pop? The impact of Wal-Mart on self-employment and small establishments in the United States. Econ Enq 46:676695. doi: 10.1111/j.1465-7295.2007.00091.x

Stone KE (1997) Impact of the Wal-Mart phenomenon on rural communities. Proceedings, Increasing Understanding of Public Problems and Policies, Farm Foundation, Chicago 
Zhu T, Singh V, DukesA (2011) Local competition, entry and agglomeration. Quantit Mark Econ. 9:129-154. doi: 10.1007/s11129-011-9097-0 